\title{
PENINGKATAN MOTIVASI DAN HASIL BELAJAR MATEMATIKA DENGAN MENGGUNAKAN ALAT PERAGA MEQIP PADA SISWA KELAS V SDN 001 SAMARINDA
}

\author{
Eka Juliatin $^{1}$, Nurul Hikmah ${ }^{2}$, Eka Selvi Handayani ${ }^{3}$ \\ Surel: Ekajuliatin@gmail.com
}

\begin{abstract}
This study aims to determine the increase in motivation and learning outcomes of mathematics in flat wake material in fifth grade students of SDN 001 Samarinda. The benefits of this study are for students to be more motivated in learning and teachers can improve the quality of education in the classroom. This type of research is PTK, conducted at SDN 001 Samarinda, class V (33 students) and one class teacher. Data collection techniques are observation, written test, documentation. The results of this study indicate that student learning outcomes can improve. This is evidenced by the existence of an increase in the average learning outcomes, in the first cycle the average grade of 55.92 with a classical percentage of 27\%, the second cycle of the average grade of 75.75 with a classical percentage of $70 \%$, in the third cycle the average value class 81,15 and the classical percentage is $94 \%$. The conclusion of the study from cycle I to cycle III motivation and learning outcomes of students in grade V SDN 001 Samarinda, there was an increase in each cycle.
\end{abstract}

Keywords : Motivation, Learning Outcomes, Flat Build, MEQIP Props

\begin{abstract}
ABSTRAK
Penelitian ini bertujuan untuk mengetahui peningkatan motivasi dan hasil belajar matematika materi bangun datar pada siswa kelas V SDN 001 Samarinda.Manfaat penelitian ini agar siswa lebih termotivasi dalam pembelajaran dan guru dapat meningkatkan mutu pendidikan di kelas. Jenis penelitian ini adalah PTK, dilaksanakan di SDN 001 Samarinda,kelas V (33 siswa) dan satu guru kelas. Teknik pengumpulan data yaitu observasi,tes tertulis,dokumentasi.Hasil penelitian ini menunjukkan bahwa hasil belajar siswa dapat meningkat.Hal ini terbukti dengan adanya peningkatan rata-rata hasil belajar, pada siklus I nilai rata-rata kelas 55,92 dengan presentase klasikal sebesar $27 \%$, siklus II nilai rata-rata kelas sebesar 75,75 dengan presentase klasikal sebesar 70\%, pada siklus III nilai rata-rata kelas 81,15 dan presentase klasikal sebesar 94\%. Kesimpulan penelitian dari siklus I hingga siklus III motivasi dan hasil belajar siswa kelas V SDN 001 Samarinda, terjadi peningkatan pada tiap-tiap siklusnya.
\end{abstract}

Kata Kunci : otivasi, Hasil Belajar, Bangun Datar, Alat Peraga MEQIP

\section{PENDAHULUAN}

Pendidikan adalah proses pemartabatan manusia menuju puncak optimal potensi kognitif, afektif, dan psikomotorik yang dimilikinya. Pendidikan adalah proses membimbing, melatih, dan memandu manusia. Pendidikan juga merupakan fenomena kemanusiaan universal yang jika benar aktivasinya akan menumbuhkembangkan multidimensi kemampuan dasar anak didik. Dalam

(1) Universitas Mulawarman Samarinda

${ }^{(2,3)}$ Universitas Widya Gama Mahakam Samarinda 
istilah ilmu pendidikan, anak didik yang disebut manusia "berpendidikan" yaitu mereka yang mampu mengoptimasikan potensi diri sebagai insan pribadi yang taat.

Matematika merupakan salah satu komponen dari serangkaian mata pelajaran yang mempunyai peranan penting dalam pendidikan. Matematika merupakan salah satu bidang ilmu pengetahuan dan teknologi. Namun sampai saat ini masih banyak siswa yang merasa matematika sebagai mata pelajaran yang sulit, tidak menyenangkan, bahkan menakutkan. Hal ini karena masih banyak siswa yang mengalami kesulitan-kesulitan dalam mengerjakan soal-soal matematika. Rendahnya daya serap siswa terhadap mata pelajaran matematika di kelas VA dimana tempat peneliti melakukan penelitian telah membuat keprihatinan. Hasil nilai ulangan harian pada sebelumnya menunjukkan 18 siswa tidak tuntas dalam belajar karena mendapatkan nilai dibawah standar yaitu 70 dari 33 siswa. Sementara 15 siswa tuntas dalam belajar. Ini menunjukkan bahwa terdapat lebih dari $54 \%$ siswa yang masih belum mencapai nilai standar yang ditetapkan oleh sekolah.

Berdasarkan latar belakang masalah maka rumusan masalah dalam penelitian ini adalah Apakah dengan menggunakan alat peraga MEQIP dapat meningkatkan motivasi dan hasil belajar siswa pada mata pelajaran matematika materi bangun datar kelas V SDN 001 Samarinda? Tujuan penelitian adalah untuk mengetahui peningkatan motivasi dan hasil belajar siswa dengan menggunakan alat peraga MEQIP pada mata pelajaran matematika materi bangun datar kelas V SDN 001 Samarinda.

\section{METODE PENELITIAN}

Penelitian ini adalah penelitian tindakan kelas. Penelitian tindakan kelas yang dalam bahasa inggris biasa disebut Clasroom Action Research (CAR) adalah penelitian tindakan (action research) yang dilakukan dengan tujuan memperbaiki mutu praktek pembelajaran di kelas. Menurut Arikunto (2010 : 12) mengemukakan bahwa penelitian tindakan kelas adalah suatu bentuk kajian yang bersifat reflektif oleh pelaku tindakan guru dalam melaksanakan tugas, memperdalam pemahaman terhadap tindakantindakan yang dilakukan serta memperbaiki kondisi dimana praktek pembelajaran tersebut dilakukan. Sedangkan menurut Hufad (2009 : 121) penelitian tindakan kelas merupakan penelitian yang menekankan kepada perbuatan untuk mengadakan perbaikan, keputusan dan penentuan atas dasar pengalaman. Pada penelitian ini menggunakan model alur PTK yang dikembangkan Arikunto (2009 : 16) yang terdiri dari empat tahap yaitu perncanaan, pelaksanaan, pengamatan dan refleksi.

Subjek dari penelitian ini adalah seluruh siswa kelas V A di SDN 001 Samarinda berjumlah 33 siswa dan guru kelas. 
Pelaksanaan Penelitian ini dilaksanakan pada kelas V SDN 001 Samarinda. Mata pelajaran Matematika, kompetensi dasarnya adalah memahami sifat-sifat bangun datar dan luas bangun datar sederhana. Penelitian ini dilaksanakan selama dua bulan.

Penelitian ini dilakukan 3 siklus masing-masing siklus dilaksanakan 2 kali pertemuan. Pada penelitian ini menggunakan model alur PTK yang dikembangkan Arikunto (2009 : 16) yang terdiri dari empat tahap yaitu perncanaan, pelaksanaan, pengamatan dan refleksi.

Secara rinci prosedur pelaksanaan rancangan penelitian tindakan kelas untuk setiap siklus dapat diuraikan sebagai berikut :

\section{Siklus I}

- Perencanaan. Pada proses perencanaan yang dilakukan adalah membuat rencana pelaksanaan pembelajaran (rpp), menentukan materi ajar, yaitu sifat-sifat bangun datar, membuat rancangan pembelajaran dengan metode yang biasa diterapkan guru kelas, membuat alat evaluasi untuk siswa berupa lembar soal dan membuat lembar observasi

- Pelaksanaan. Pada proses pelaksanaan dilakukan dua kali pertemuan. Pertemuan pertama yaitu pelaksanaan fokus kegiatan guru dituangkan dalam kegiatan inti. Pertemuan kedua merupakan akhir dari siklus pertama. Jika pada pertemuan pertama siswa telah mempelajari tentang sifat-sifat bangun datar sederhana, maka pada pertemuan ini guru memberikan tes secara tertulis. Soal pada tes ini berupa tes essay. Pada saat tes berlangsung, siswa tidak diperbolehkan bekerjasama dan hasil tes dikumpulkan kepada guru. Guru bersama siswa membahas soal tes dan memberikan bimbingan kepada siswa yang masih belum paham.

- Observasi. Pengamatan dilakukan terhadap seluruh aktivitas pembelajaran dari awal kegiatan sampai akhir kegiatan pembelajaran siswa. Pelaksanaan pengamatan menggunakan lembar observasi yang telah disiapkan sebelumnya.

- Refleksi. Hasil perolehan data diteliti untuk selanjutnya dijadikan sebagai bahan acuan pada tahapan/ siklus berikutnya. Data tersebut dijadikan bahan untuk melakuakan refleksi untuk mengetahuai kekuatan dan kelemahan pelaksanaan pembelajaran dan hasil belajar siswa. Hasil refleksi tersebut dijadikan bahan perbaikan untuk siklus kedua.

\section{Siklus II}

Perencanaan siklus II dilaksanakan pada tahap perbaikan RPP, khususnya pada kegiatan inti sesuai dengan hasil refleksi pada siklus I. Pada alat evaluasi serta lembar observasi harus dipastikan kelengkapan data. Dari hasil refleksi siklus I, maka diadakan perencaanaan ulang pada siklus II yaitu: analisis masalah siklus i yang belum berhasil, 
menyusun strategi belajar mengajar dengan menggunakan alat peraga untuk lebih meningkatkan motivasi belajar siswa, guru menyusun rpp, guru menentukan pokok bahasan yang diajarkan, yaitu sifat-sifat bangun datar, serta merancang lembar observasi.

Pelaksanaan.

Tahap pelaksanaan didalam siklus II ini pelaksanaannya disesuiakan dengan perbaikan RPP, skenario pembelajaran tidak jauh berbeda dengan pelaksanaan di siklus I. Pertemuan kedua pada siklus ini merupakan akhir dari siklus kedua. Jika pada pertemuan pertama siswa telah mempelajari tentang sifat-sifat bangun datar sederhana, maka pada pertemuan ini guru memberikan tes secara tertulis. Soal pada tes ini berupa tes essay. Pada saat tes berlangsung, siswa tidak diperbolehkan bekerja sama dan hasil tes dikumpulkan kepada guru. Guru bersama siswa membahas soal tes dan memberikan bimbingan kepada siswa yang masih belum paham.

Tidak jauh berbeda dengan pengamatan pada siklus I, di siklus II ini pengamatan lebih difokuskan pada pelaksanaan penggunaan alat peraga MEQIP serta keaktifan siswa dalam pelaksanaan pembelajaran. Untuk mengetahui hasil belajar dari siswa, maka dilakukan tes secara tertulis.

Seluruh kegiatan yang dilakukan mulai dari siklus I yaitu pada hasil observasi kegiatan perbaiakan pembelajaran serta hasil evaluasi tertulis dijadikan bahan untuk melakukan refleksi. Kegiatan ini bertujuan untuk mengetahui kelebihan serta kelemahan pelaksanaan pembelajaran dan hasil belajar siswa. Hasil refleksi pada siklus II diharapkan sudah berhasil, sehingga tidak perlu lagi melanjutkan pada tahap siklus III. Jika pada siklus II masih belum berhasil, akan dilanjutkan pada tahap siklus III.

\section{Siklus III}

Siklus III ini bertujuan untuk memperbaiki kekurangan-kekurangan yang terdapat pada siklus II, sebagai tindak lanjut untuk mencapai hasil yang memuaskan. Hasil refleksi pada siklus II jika dianggap belum berhasil, maka diadakan perencanaan ulang pada siklus III.

Pelaksanaan pertama siklus III dilakukan melalui kegiatan sebagai berikut : guru menyiapkan alat peraga meqip yang akan digunakan, guru menjelaskan alat peraga yang akan digunakan kepada siswa, guru menjelaskan materi menghitung luas bangun datar dengan menggunakan alat peraga meqip, guru melakukan tanya jawab dengan siswa menggunakan alat peraga meqip, guru memberikan bimbingan pada siswa yang belum memahami serta guru bersama siswa menyimpulkan materi yang telah dipelajari.

Pertemuan kedua merupakan pertemuan terakhir dari tiap-tiap siklus, sehingga pada pertemuan kedua ini merupakan pertemuan terakhir pada siklus III. Setelah siswa menggunakan alat peraga MEQIP selama dua kali pertemuan yaitu pada siklus II pertemuan pertama dan siklus III pertemuan pertama, maka pada 
pertemuan ini diadakan kembali tes tertullis berupa soal essay. Pada saat tes berlangsung siswa dilarang bekerja sama. Hasil tes dikumpulkan, kemudian guru bersama siswa membahas soal tes tersebut. Guru memberikan bimbingan pada siswa yang belum paham.

Peneliti menganalisis semua tindakan pada siklus I, II, dan siklus III. Kemudian melakukan refleksi terhadap pembelajaran yang dilakukan dalam tindakan kelas. Pada tahap ini akan dapat diketahui apakah dengan menggunakan alat peraga MEQIP berhasil meningkatkan motivasi dan hasil belajar matematika materi bangun datar kelas V SDN 001 Samarinda.
Teknik Pengumpulan data dalam penelitian ini adalah tes tertulis, observasi dan dokumentasi. Untuk menganalisis tingkat keberhasilan siswa setelah proses belajar mengajar setiap siklus dilakukan dengan cara memberikan evaluasi berupa soal tes tertulis setiap akhir siklus.

\section{HASIL PENELITIAN DAN PEMBAHASAN}

Penelitian ini dilaksanakan di SDN 001 Samarinda. Siswa yang dikenakan tindakan adalah kelas V A yang berjumlah 33 siswa.

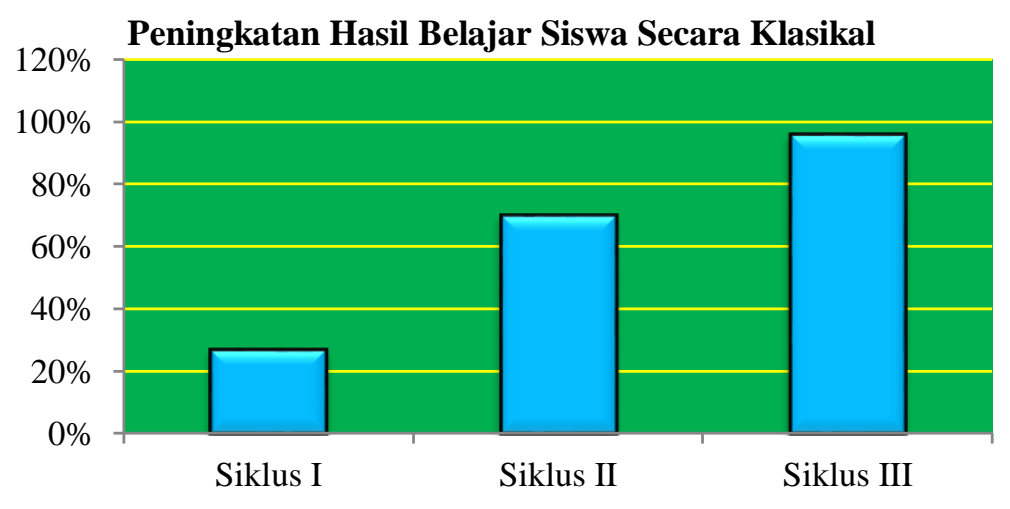

\section{Gambar 1. Diagram Peningkatan Hasil Belajar Atau Ketuntasan Belajar Siswa Secara Klasikal}

$\begin{array}{ll}\text { Berdasarkan grafik dapat } & \text { mengalami ketuntasan belajar. Pada } \\ \text { diketahui jumlah peningkatan siswa } & \text { siklus II terdapat 70\% siswa yang } \\ \text { yang mengalami ketuntasan belajar } & \text { mengalami ketuntasan belajar, pada } \\ \text { dengan memperoleh nilai diatas KKM } & \text { siklus II terjadi peningkatan sebesar } \\ \text { pada setiap siklusnya. Pada siklus I } & 43 \% \text { tetapi belum mencapai } \\ \text { terdapat 27\% siswa yang mengalami } & \text { ketuntasan secara klasikal. Pada siklus } \\ \text { ketuntasan belajar. Pada siklus Ibelum } & \text { III terdapat } 96 \% \text { siswa yang mencapai } \\ \text { tercapai ketuntasan secara klasikal } & \text { ketuntasan, pada siklus ini terjadi } \\ \text { karena ketuntasan secara klasikal } & \text { peningkatan ketuntasan belajar } \\ \text { terjadi apabila } 80 \% \text { siswa telah } & \text { sebesar } 26 \% \text { dari siklus II dan telah }\end{array}$


mecapai ketuntasan secara klasikal karena telah mencapai lebih dari $80 \%$.

Tabel 1. Data Peningkatan Motivasi Belajar Siswa

\begin{tabular}{l|c|c|c|c|c|c}
\hline \multirow{2}{*}{$\begin{array}{c}\text { Aspek } \\
\text { Motivasi }\end{array}$} & \multicolumn{2}{|c|}{ Siklus I } & \multicolumn{2}{c|}{ Siklus II } & \multicolumn{2}{c}{ Siklus III } \\
\cline { 2 - 7 } & J & P (\%) & J & P (\%) & J & P (\%) \\
\hline Minat & 9 & 28 & 31 & 94 & 33 & 100 \\
\hline Perhatian & 7 & 21 & 23 & 70 & 32 & 97 \\
\hline Partisipasi & 5 & 16 & 20 & 60 & 31 & 94 \\
\hline $\begin{array}{l}\text { Presentase } \\
\text { Rata-Rata } \\
\text { Keseluruhan }\end{array}$ & & 21,67 & & 74,67 & & 97 \\
\hline
\end{tabular}

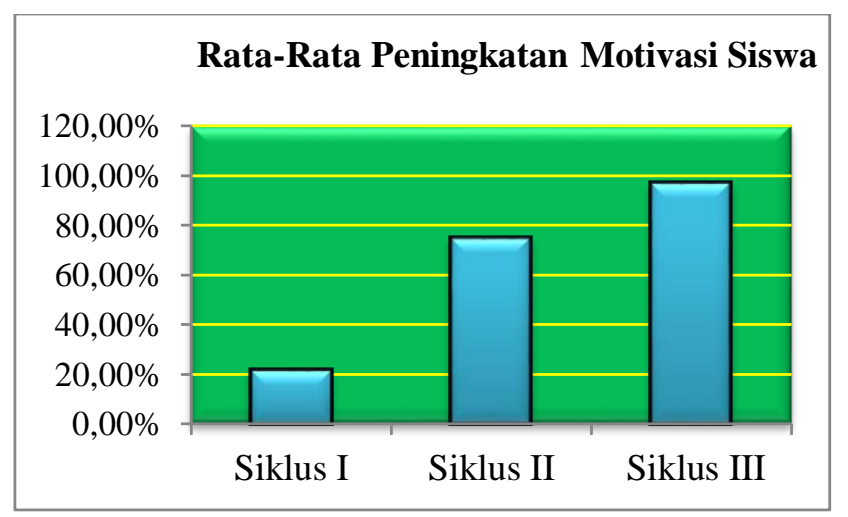

\section{Gambar 2. Diagram Rata-Rata Peningkatan Motivasi Belajar Siswa}

Berdasarkan grafik dapat diketahui peningkatan motivasi belajar siswa pada tiap siklus. Pada siklus I presentase rata-rata motivasi siswa adalah 21,67\%, pada siklus II presentase rata-rata motivasi siswa adalah $74,67 \%$, dan pada siklus III presentase rata-rata motivasi siswa adalah 97\%. Dari siklus I ke siklus II terjadi peningkatan motivasi siswa sebesar 53\% dan pada siklus II ke siklus III terjadi peningkatan motivasi sebesar $22,33 \%$.

\section{Pembahasan}

Siklus I

Siklus I menunjukkan nilai akhir rata-rata siswa adalah 55,92 dengan kriteria sangat kurang sekali. Peneliti yang bertindak sebagai guru kelas mengajar dengan metode yang biasa digunakan pada pembelajaran sebelumnya dan menggunakan metode gambar pada umumnya. Pada siklus ini presentase belajar siswa masih sangat jauh dari presentase klasikal, hal ini yang menjadi dasar perlu 
dilakukannya tindakan pada subjek yaitu siswa kelas VA SDN 001 Samarinda g yang berjumlah 33 siswa dan 1 guru kelas.

Motivasi siswa dalam belajar pada siklus I masih sangat kurang, minat, perhatian dan partisipasi siswa dalam belajar masih sangat kurang, sehingga masih perlu diperbaiki dalam memberikan motivasi pada siswa agar siswa berminat, memperhatikan dan berpartisipasi dalam kegiatan pembelajaran. Pada siklus I terdapat 24 siswa yang tidak tuntas dalam mengerjakan soal yang diberikan guru dengan nilai rata-rata kelas 55,92 dan presentase sebesar $73 \%$ dan untuk siswa yang tuntas sebanyak 9 siswa dengan presentase ketuntasan klasikal sebesar $27 \%$.

Peneliti dan guru kelas secara bersama perlu mengadakan tindakan yang dilakukan untuk meningkatkan motivasi dan hasil belajar. Hal-hal yang perlu dilakukan adalah untuk meningkatkan minat siswa dalam belajar adalah dengan menggunakan media yang menarik bagi siswa, untuk meningkatkan perhatian siswa dalam belajar, guru lebih sering bertanya pada siswa yang dianggap tidak atau kurang memperhatikan, dan unruk meningkatkan partisipasi siswa dalam belajar, guru meminta siswa untuk menggunakan media pembelajaran.

\section{Siklus II}

Alat peraga MEQIP yang merupakan media pembelajaran yang dirancang khusus dan didesai dengan warna-warna yang menarik dan banyak disukai anak-anak, sehingga dengan menggunakan alat peraga MEQIP dapat menciptakan suasana kelas yang menyenangkan. Bimbingan yang diberikan guru pada siklus II sudah sangat baik, guru telah mampu menarik perhatian siswa untuk berminat, memperhatikan penjelasan guru, dan partisipasi siswa dalam mengikuti pembelajaran. Hal-hal tersebut merupakan aspek-aspek dalam memotivasi siswa. Dengan guru mampu memotivasi siwa dalam mengikuti pembelajaran secara baik, maka hasil pembelajaran juga mengalami peningkatan, ditunjukkan dengan penurunan jumlah siswa yang tidak tuntas dalam mengerjakan tugas yang diberikan guru yaitu sebesar 10 siswa, presentase sebesar $30 \%$ dengan nilai rata-rata kelas 75,75 dan presentase ketuntasan klasikal sebesar $70 \%$. Hasil analisis data diperoleh bahwa pada siklus II telah mencapai presentase ketuntasan belajar klasikal sebesar70\%. Ini menunjukkan adanya peningkatan dari siklus I ke siklus II sebesar 43\%. Berdasarkan kesepakatan sebelumnya bahwa penelitian dianggap berhasil apabila presentase ketuntasana belajar secara klasikal mencapai $80 \%$. Pada siklus ini belum tercapai presentase ketuntasan sebesar 80\%, sehingga akan dilanjutkan penelitian pada siklus selanjutnya dengan pertimbangan hasil refleksi sebagai berikut: motivasi siswa dalam belajar masih banyak yang belum mencapai skor maksimal, motivasi tersebut mencakup minat, perhatian, dan partisipasi. Dalam hal ini guru akan lebih mengeksplor tentang media yang digunakan. 


\section{Siklus III}

Peneliti pada siklus III ini masih berperan sebagai guru kelas. Pada siklus III ini masih menggunakan alat peraga $M E Q I P$ pada subjek penelitian yaitu siswa kelas VA SDN 001 Samarinda, siklus III ini merupakan kelanjutan dari siklus II yang dinilai belum berhasil karena masih terdapat beberapa kekurangan sehingga perlu adanya perbaikan. Pada siklus III ini hasil pembelajaran siswa secara menyeluruh telah mencapai kategori sangat baik. Hal ini dapat ditunjukkan dengan meningkatnya motivasi siswa dalam belajar. Minat, perhatian dan partisipasi siswa pada siklus III semakin meningkat dari siklus sebelumnya. Guru mampu menimbulkan rasa ingin tahu anak melalui alat peraga MEQIP yang digunakan dalam membantu proses belajar mengajar, partisipasi siswa dalam penggunaan alat peraga $M E Q I P$ juga semakin meningkat serta siswa lebih mampu memahami konsep abstrak matematika. Guru dalam hal penggunaan alat peraga $M E Q I P$ juga mampu membuat siswa bersemangat dan pembelajaran matematika menjadi menyenangkan. Pada siklus III terdapat 2 siswa yang tidak tuntas dalam mengerjakan tugas yang diberikan oleh guru dan terdapat 31 siswa yang tuntas dalam mengerjakan tugas yang diberikan oleh guru. Nilai rata-rata ketuntasan kelas adalah 81,15 dengan presentase ketuntasan secara klasikal sebesar 94\%. Hasil analisis siklus III menunjukkan bahwa presentase ketuntasan secara klasikal sebesar 94\%, dengan demikian dapat dinyatakan bahwa penelitian ini telah berhasil mencapai target yang telah disepakati yaitu presentase ketuntasan secara klasikal sebesar $80 \%$. Berdasarkan hasil refleksi juga diperoleh bahwa pembelajaran telah berlangsung dengan baik dan stbil. Hal ini dapat ditunjukkan dengan peningkatan dari siklus-siklus sebelumnya. Dengan pencapaian yang didapat dari siklus I, II dan III, maka guru sebagai peneliti dan observer sepakat untuk menghentikan penelitian sampai di siklus III.

\section{SIMPULAN}

Hasil tes belajar siswa terjadi peningkatan pada setiap siklusnya, yaitu pada siklus I terdapat 24 siswa yang tidak tuntas belajar dan terdapat 9 siswa yang tuntas belajar, dengan nilai rata-rata kelas 55,92 dan presentase nilai rata-rata ketuntasan secara klasikal sebesar 27\%. Pada siklus II terdapat 10 siswa yang tidak tuntas dalam belajar dan 23 siswa yang tuntas belajar, dengan nilai rata-rata kelas 75,75 dan presentase nilai ratarata ketuntasan secara klasikal sebesar $70 \%$, sehingga terjadi peningkatan sebesar $43 \%$ dari siklus I ke siklus II. Pada siklus III terdapat 2 siswa yang tidak tuntas belajar dan terdapat 31 siswa yang tuntas belajar, dengan nilai rata-rata kelas 81,15 dan presentase nilai rata-rata ketuntasan secara klasikal sebesar 94\% sehingga terjadi peningkatan sebesar $24 \%$ dari siklus II ke siklus III.

Hasil observasi belajar siswa terjadi peningkatan pada setiap 
siklusnya adalah sebagai berikut, pada siklus I presentase rata-rata motivasi siswa adalah $21,67 \%$, pada siklus II presentase rata-rata motivasi siswa adalah $74,67 \%$, dan pada siklus III presentase rata-rata motivasi siswa adalah $97 \%$. Dari siklus I ke siklus II terjadi peningkatan motivasi siswa sebesar $53 \%$ dan pada siklus II ke siklus III terjadi peningkatan motivasi sebesar $22,33 \%$.

\section{DAFTAR RUJUKAN}

Arikunto, Suharsimi. 2009. Penelitian Tindakan Kelas. Jakarta: PT Bumi Aksara

Arikunto, Suharsimi. 2010. Dasardasar Evaluasi Pendidikan. Jakarta : PT Bumi Aksara

Hufad, Achmad. 2009. Penelitian Tindakan Kelas. Jakarta: Direktorat Jenderal Pendidikan Islam Departemen Agama

Eveline.2010. Teori Belajar dan pembelajaran. Bogor: Ghalia Indonesia.

Mudijono.2006. Strategi Belajar Mengajar. Jakarta: Rineka Cipta

Ngalim, Purwanto. 2008. Evaluasi Pengajaran. Bandung: Remaja Rosda Karya

Riduwan. 2011. Dasar-dasar Statistika. Bandung: Alfabeta

Rusman. 2012. Belajar dan Pembelajaran Berbasis Komputer. Bandung: Alfabeta.

Slameto. 2010. Belajar dan FaktorFaktor yang Mempengaruhi. Jakarta: Rineka Cipta.
Sudjana, Nana. 2009. Penilaian Hasil Proses Belajar Mengajar. Bandung: PT Remaja Rosdakarya

Sukayati, dkk. 2007. Mathematics Education Quality Improvement Program (MEQIP). Yogyakarta: Empat Pilar Pendidikan.

Sundayana Rostina. 2013. Media Pembelajaran Matematika. Bandung: Alfabeta.

Suprijono, Agus. 2009. Cooperative Learning Teori dan Aplikasi PAIKEM. Yogyakarta: Pustaka Pelajar. 